DOI https://doi.org/10.30929/2307-9770.2019.07.01.04

UDC 378.147:377]:63](477)(043.3)

\title{
Implementation of heuristic learning technologies for theoretic concepts formation by students mastering agricultural professions
}

\author{
Bilotserkovets M. ${ }^{*}$, Berestok 0. \\ Sumy National Agrarian University, Sumy, Ukraine
}

Received: $10.03 .2019 \quad$ Accepted: 20.03 .2019

\begin{abstract}
The paper studies nature and specific features of heuristic learning technologies, significant for the formation of theoretical knowledge by students of agrarian specialties in their course of humanities. Analysis of up-todate scientific works reveals the efficiency of the process of humanitarian theoretical knowledge formation by students due to the involvement of a set of important pedagogical factors, such as: motivation of students by setting ties between humanitarian theoretical concepts and their future professional activities; creation and competent defense of personally essential educational products; teaching students to apply heuristic learning technologies (methods for defining theoretical concepts, methods and tools of dialogue interaction in solving complex professional problems, reflexive conclusions, heuristic analytical and comparative learning activities, prediction of the possible outcome of the educational activity and visual representation of its image etc.). The experimental survey was aimed to determine the stages of a humanitarian theoretic concept formation based on the heuristic learning technologies. The first motivational stage provides students' awareness of necessity of the humanitarian theoretical concept that is being formed for their future professional activity. The next searching-creative stage is carried out with various methods and mechanisms of heuristic learning technologies, mastered by students under the conditions of individual creation of educational products. At the reflection stage a teacher and students use pedagogical diagnostic mechanisms to assess the level of formation of the theoretical concept, the level of mastering basic theoretical and practical aspects of the topic as well as the development of critical and creative thinking and professional competences of future specialists in agriculture, their ability to form the necessary knowledge independently. So, heuristic learning activities enable students to segment and study the specific areas of their future professional activity from humanitarian perspectives and establish personal motives for learning humanities.

Key words: heuristic learning technologies, theoretic knowledge, humanities.
\end{abstract}

\section{Впровадження евристичних технологій навчання для формування теоретичних понять студентами-аграріями}

Білоцерковець М. А., Бересток О. В.

Сумський національний аграрний університет, Суми, Україна

\begin{abstract}
Анотація. Досліджено сутність та особливості евристичних технологій навчання, які є важливими для формування теоретичних знань студентів аграрних спеціальностей у їхньому освоєнні гуманітарних дисциплін. Аналіз сучасних наукових праць показує ефективність процесу формування гуманітарних теоретичних знань студентами за умови залучення низки важливих педагогічних чинників, таких як: мотивація студентів шляхом встановлення зв'язків між гуманітарними теоретичними поняттями та їхньою майбутньою професійною діяльністю; створення та захист особисто значущих освітніх продуктів; навчання студентів застосовувати технології евристичної освіти (методів визначення теоретичних понять, методів і засобів діалогової взаємодії при вирішенні складних професійних завдань, рефолексивних висновків, евристичної аналітичної та порівняльної навчальної діяльності, прогнозування можливого результату навчальної діяльності та її візуалізації тощо). Метою експериментального дослідження було визначити етапи формування гуманітарного теоретичного поняття на основі евристичних технологій навчання. Перший етап - мотиваційний - забезпечує усвідомлення студентами необхідності гуманітарного теоретичного поняття, що формується, для їх майбутньої профессійної діяльності. Наступний, пошуково-творчий етап здійснюється за допомогою різних методів і механізмів евристичних технологій навчання, освоєних студентами в умовах самостійного створення
\end{abstract}

Corresponding Author: Bilotserkovets Marina.Tel. +38(066)007-69-04. E-mail: mbelotserkovets@yahoo.com Sumy National Agrarian University, G. Kondratyev Street, 160, Sumy, Ukraine, 40000.

Відповідальний автор: Білоцерковець Марина Анатоліївна. +38(066)007-69-04. E-mail: mbelotserkovets@yahoo.com Сумський національний аграрний університет, вул. Г. Кондратєва, 160, Суми, Україна, 40000. 
освітніх продуктів. На етапі рефлексії викладач та студенти використовують педагогічні діагностичні механізми для оцінки рівня формування теоретичного поняття, рівня оволодіння основними теоретичними та практичними аспектами теми, а також розвитку критичного та творчого мислення та професійних компетентностей майбутніх фахівців у сільському господарстві, їхньої здатності самостійно формувати необхідні знання. Таким чином, евристична навчальна діяльність дає змогу студентам сегментувати і вивчати конкретні сфери своєї майбутньої професійної діяльності з гуманітарних перспектив і встановлювати особистісні мотиви для вивчення гуманітарних дисциплін.

Ключові слова: евристичні технології навчання, теоретичні знання, гуманітарні дисципліни.

\title{
Использование эвристических технологий обучения для формирования теоретических понятий студентами-аграриями
}

\author{
Белоцерковец М. А., Бересток О. В. \\ Сумской национальный аграрный университет, Сумы, Украина
}

\begin{abstract}
Аннотация. В статье рассматриваются сущность и особенности эвристических образовательных технологий, значимых для формирования теоретических знаний у студентов аграрных специальностей в их изучении гуманитарных дисциплин. Анализ современных научных работ выявляет эфффективность процесса формирования студентами гуманитарных теоретических знаний с использованием ряда важных педагогических факторов, таких как: мотивация студентов путем установления связей между гуманитарными теоретическими понятиями и их будущей профессиональной деятельностью; создание и защита личностно значимых образовательных продуктов; обучение студентов применению эвристических образовательных технологий (методы определения теоретических понятий, методы и средства диалогового взаимодействия при решении сложных профессиональных задач, рефрлексивные выводы, эвристические аналитические и сравнительные виды учебной деятельности, прогнозирование возможных результатов учебной деятельности и ее визуализация и т.д.). Экспериментальное исследование было направлено на определение этапов формирования теоретического гуманитарного понятия на основе эвристических технологий обучения. Первый мотивационный этап обеспечивает понимание студентами необходимости гуманитарного теоретического понятия, которое формируется для их будущей профессиональной деятельности. Следующий, поисково-творческий этап осуществляется с использованием различных методов и механизмов эвристических технологий обучения, освоенных студентами в условиях самостоятельного создания образовательных продуктов. На этапе рефрлексии преподаватель и студенты используют механизмы педагогической диагностики для оценки уровня формирования теоретического понятия, уровня освоения базовых теоретических и практических аспектов темы, а также развития критического и творческого мышления и профессиональных компетентностей будущих специалистов по сельскому хозяйству, их способностей самостоятельно формировать необходимые знания. Таким образом, эвристическая учебная деятельность позволяет студентам сегментировать и изучать конкретные области своей будущей профессиональной деятельности с гуманитарной точки зрения и устанавливать личностые мотивы для изучения гуманитарных дисциплин.
\end{abstract}

Ключевые слова: эвристические технологии обучения, теоретические знания, гуманитарные дисциплины.

\section{Introduction}

Heuristic learning technologies are innovative learning technologies created on the basis of heuristic methods and mechanisms that demand application of motivational principles; systematization and generalization of knowledge and skills, methods of creative activity (various kinds of creative individual work, such as educational projects, open heuristic tests and situational tasks, writing short scientific abstracts, etc.); creation and presentation of personally significant educational product as a result of individual creative work; reflection and correction of the creative work outcomes performed in order to improve them and obtain a higher mark.

The nature of heuristic learning in the modern sense is not so much in transferring the past experience to students, but in acquiring their own educational experience, cultural enhancement, professional knowledge, ethic values [1]. The classical knowledge paradigm is grounded on the rational distraction, intellectual efforts, reproduction, memorization, description, general logic; meanwhile the heuristic paradigm emphasizes on the ability of the learners to understand the foundations of knowledge formation and their insight potential. 
Students construct independently their own educational motives, formulate personally meaningful goals and objectives.

At present, according to American and British scholars (Beaty, Silvia, Nusbaum, Jauk, and Benedek), who explored the efficiency of such heuristic technologies as associative and executive processes in creative cognition, modern pedagogy needs to review the heuristic paradigm of teaching and studying at a higher school, since the content and methods of traditional education do not meet the requirements and challenges of today, as every three to five years the amount of scientific information is multiplied, and human capacity is not able to absorb the increasing amount of general and professional knowledge [3]. That is why the scientific search for many scholars and researchers in education abroad (Gigerenzer, Gaissmaier, Klopfer, Osterweil, Salen, Tempelaar, Rienties, Nguyen) is also focused on the development of heuristic learning technologies that are primarily aimed to master the methods of obtaining knowledge, ways of its structuring and transforming for the purposes of active practical activity [7, 14, 23]. In Ukraine a significant contribution to the development of heuristic learning technologies was made by the scientific school of Sumy State Pedagogical University named after A. S. Makarenko run by Professor M. Lazarev. The innovative technology of heuristic learning for students was introduced there on the theoretical, experimental and methodological levels. The content of the new technology refers primarily to the modified structure of the academic process, which consists mostly of the heuristic searching-creative activity of a teacher and students [1].

The aim of the article is to specify the peculiarities of heuristic learning technologies and determine the stages of a humanitarian theoretic concept formation on their basis.

\section{Materials and Methods}

The concept of "heuristic learning" appeared in pedagogy relatively recently, although it has an ancient origin. The word "heuristic" comes from the Greek word "heurisco", which means "I invented". Elements of heuristic learning, in terms of active self-mastery of students in gaining knowledge, were used by prominent thinkers of antiquity (Socrates, Arhite, Aristocles, Plato, Pythagoras). They proceeded in their arguments from the judgments that the development of human thinking could be successfully carried out solely by independent search and active learning activity performed by learners [17].

Rasmussen underlined the most important thing about learning that it would no longer be based on memorization: due to the modern technology, any information might be available in an instant. Students should not overload their brains with useless knowledge, on the contrary, their mental reserve ought to be released for the development of abilities to think, analyze, argue and finally make the right decisions [20].

Kenett, Anaki and Faust, while investigating the structure of semantic networks in low and high creative persons noted that the most widespread American high school and secondary school heuristic technology is project activity of students. Its merits are grounded on implementation of research, simulation, and role play methods, primarily aimed at gaining and practical use of basic theoretical knowledge [12]. Benedek, Jauk, Sommer, Arendasy, and Neubauer studied the whole set of heuristic technologies and mechanisms relating to the comprehension of the educational problems, a series of enquiring, researching, refining and evaluation questions concerning the components of an educational topic, as well as a set of mechanisms of new knowledge construction and its evaluation. The main educational strategy is the creation of personally significant educational product by students in the process of cognitive and creative activity. Researchers pointed out that the purpose of learning is not only to achieve the result, but also to master the modes of activity (mechanisms, methods, techniques of constructive and diagnostic actions), which are indispensable for the educational product accomplishing [5].

A thorough analysis of the key principles of heuristic learning was carried out in the works by Gigerenzer and Gaissmaier, regarding specific conditions of the subject mastering and its reflexive awareness [7]. According to Katsikopoulos, reflection is a prerequisite for students and a teacher to speculate on the organization of educational activities, organize them in accordance with educational objectives and programs, and realize the emerging issues and other outcomes [11].

As for the actual formation of theoretical knowledge, the mastery of the theoretical material, its individual and deep comprehension depends on the systematic implementation of heuristic learning technologies. Students are presented the new theoretic concepts with various heuristic technologies and mechanisms of searching-creative activity. They learn to transform the definitions of the basic concepts, to interpret 
regularities, generalize them in accordance with their own understanding and degree of readiness, pose problematic, heuristic questions to the topic, and then look for various methodic, scientific and multimedia sources in order to answer - verbally or in writing - on certain problem issues aimed to increase the acquired theoretical knowledge [1, 2].

However, theoretical knowledge formation on humanities is primarily the mastery of the system of its concepts, which consists of comprehension of the content, the allocation of core categories, substantial in certain subjects, phenomena, relevant in the scope of the system of concepts, ideas and theories. It includes also the ability to establish ties with the concepts of related disciplines and the ability to use them solving practical problems [22].

Using the tools of heuristic learning, students form theoretical knowledge of humanities, for instance, knowledge of a foreign language, guided by their own educational potential. Heuristic learning technologies for the formation of theoretical knowledge are focused on intense individual creativity of students, since it is creativity that is the basis of heuristic education. Internal need for creative activity is considered by psychologists and educators (Ben-Horin, Pion and Kali) as an objective pattern of personality development [6]. Students of agrarian universities learn a foreign language for everyday communication during the practical training at agricultural enterprises abroad and participation in international academic mobility programs. That is why one of the main tasks in teaching foreign languages for students of non-language faculties is, in particular, the formation of a certain stock of theoretical language knowledge, which will become the basis for developing the whole set of linguistic competences and practical skills of communication in a foreign language.

Analysis of the problem of heuristic learning technologies implementation for the formation of theoretical knowledge of students enabled establishing necessary tools and stages for mastering theoretic concepts by students of agrarian specialties in the process of learning humanities, among them stimulating cognitive activity of students, creating their own professional motivation; applying methods, techniques and mechanisms of searching-creative activity.

\section{Results}

The experimental study of humanitarian theoretical knowledge formation of students mastering agricultural professions took place in Sumy National Agrarian University. It was a purposeful process of students' implementation of heuristic learning technologies in solving situational tasks from the scope of their future professional activities. Heuristic learning involves sufficient mastering of mechanisms, methods and techniques of creative activity, such as "analysis through synthesis", brainstorming, a logical set of heuristic questions, methods of developing empirical knowledge to the theoretical level, association, comparison, generalization, abstraction, objective and detailed diagnostics for evaluating educational outcomes, etc. It provides real learners' autonomy, creativity and their continuous interaction with teachers. Moreover, heuristic learning technologies involve evaluating the results of achievements due to the internal and external products of students' individual activity, which can be improved, corrected, changed within a certain time frame.

The discipline "Foreign language of professional use" organically combines practical and theoretical materials. The use of numerous terms, different names of the same phenomena and processes for various components of linguistic competences enables generalization of the diverse materials and their systematization. All this determines the need to work with various aspects of the system of concepts, which involves a careful attitude to the process of their formation and the creation of conditions for the development of students' heuristic and creative thinking in the process of learning.

For instance, heuristic approach to the introduction of the concept of "competence" requires the transition from the consideration of simple, empirical causal ties to generalized and at the same time quite formalized formulation of these ties, to the abstraction, which transfers this concept into higher, theoretical level of its development and organization. It should be noted that this concept is the result of a certain stage in the development of knowledge and ideas of students about professionally oriented theoretical concept in the up-to-date paradigm of education. The interpretation of the concept of "competence" is considered theoretically within the conceptual system of personally oriented teaching. The teacher explains that competence is the quintessence of targeted, meaningful, semantic, creative, emotional, and valuable characteristics of a person. Realizing the polysemy (ambiguity) of this concept, a group of students conducts 
an analysis first of its categorical series, that is, the system of concepts that form its content, and then considers the categorical context, that is, the external conceptual environment, within which there is also a certain specificity. The teacher notes that the competences that are formed by students, are multifaceted, multidisciplinary characteristics of an individual, subject to the influence of a huge number of external and internal factors. They cannot be defined only as a set of knowledge and skills in a certain discipline, since the spectrum of properties and functions of this concept is quite broad, and therefore students can construct their own models of this concept, forming the general (system) model.

It is important to emphasize on the need for theoretical knowledge of grammar for professionally oriented sources to be properly understood and translated from and into in a foreign language. While forming grammatical concepts, a teacher prepares learning material using reference signals, which distinguish the signs-markers of grammatical phenomena (suffixes, endings, auxiliary forms, etc.), in order to grasp the nature of a theoretical concept. Such reference signals are aimed at establishing structural and semantic correlations of foreign and native languages. A teacher presents a new learning information in the form of a heuristic conversation or uses a heuristic mechanism of "brainstorming" using reference signals in the form of tables or recorded on the board. Signs are highlighted with arrows, symbols are desirable to draw in contrasting colors, creating a reference abstract as an educational product for students' heuristics. When students achieve a sufficient level of mastering heuristics, the teacher suggests identifying and creating reference signals on their own.

For example, forming a grammatical concept "infinitive", the teacher asks students to identify by themselves the morphological features of this phenomenon, find analogies with the concept of impersonal verb forms in their native language, and determine the functions and meaning of the infinitive depending on its place in the sentence. Thus, students examine different aspects of scientific interpretations of the concept and are able to construct the actual definition of the theoretical concept of "infinitive" on their own. At the final stage of the formation of the grammatical concept, students construct their own definition and illustrate it with examples of personal speaking activity, thus implementing the principle of heuristic education on the construction of the personal content of education by students.

During practical classes, both traditional and heuristic assignments are used, however, heuristic ones prevail, as they provide profound and aware forming of theoretic concepts and focus equally on learning and control. Perception and comprehension of the learning material are closely connected with the pedagogical diagnostic of level of its formation. A significant feature of implementation of heuristic assignments is that the whole group of students is involved in this activity. Another feature is its intense nature: to think over and discuss any problematic issue, students are given a limited amount of time depending on the complexity of an issue. Naturally, most heuristic tasks are intended to be done in the classroom with a teacher, while the training exercises are performed mainly as homework.

Analysis of scientific sources and the experimental survey resulted in singling out the stages of humanitarian theoretical concept formation based on heuristic learning technologies as follows, motivational, searching -creative, reflection.

At the first motivational stage the students realize the need for the humanitarian theoretical concept that is being formed and its connection with their future professional activity.

At the next, searching-creative stage the formation of the humanitarian theoretical concept is carried out using heuristic learning technologies, various methods and mechanisms of searching and creative activity, mastered by students.

At the last reflection stage, the teacher and the students determine the level of formation of the theoretical concept by means of pedagogical diagnostic mechanisms.

Figure 1 presents graphically the stages of humanitarian theoretic concept formation by students mastering agricultural professions. 


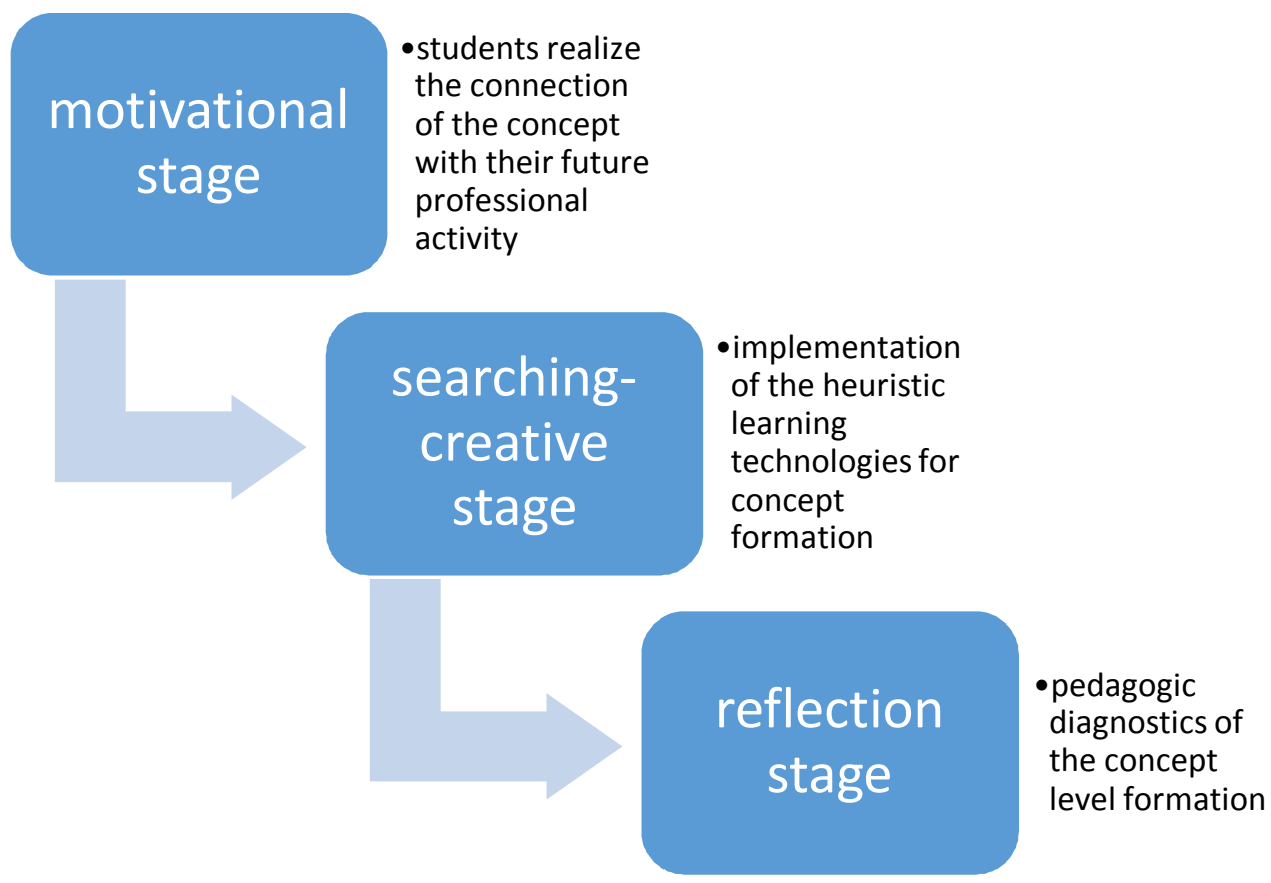

Fig. 1. The stages of a humanitarian theoretic concept formation based on the implementation of heuristic learning technologies

\section{Discussion}

Katsikopoulos and Ormond proved that the effectiveness of heuristic learning activity is not provided by the repeated performance of educational activities (for example, the large number of exercises, tasks, etc.), but it is gained through the implementation of a comparative analysis that lead to the corresponding reflexive conclusions [11, 18]. According to Bago and De Neys, heuristic analytical and comparative learning activities help students to segment and study the specific areas of future professional activity in which they specialize from humanitarian perspectives. This position is especially relevant for the formation of humanitarian theoretical concepts, characterized by complexity (the ability to synthesize the studied disciplines) and personalized aspect (personal position and perspectives towards the subject). The key strategy for developing a students' personalized aspect is to acquire a system of theoretical knowledge, and skills in accordance to the field of future professional activity [3].

Sale notes that the acquisition of knowledge takes place on four levels: conscious perception, memory (reproduction), application of knowledge according to the model (in a familiar situation), and a creative application of knowledge (in an unfamiliar situation). Four levels of assimilation (acquaintance, reproduction, full knowledge, transformation) characterize the results achieved, the four levels of cognitive activity (information, reproduction, problem-solving, heuristic research) are the ways of achieving them [21].

Kurzban, Duckworth, Kable and Myers claim that effective formation of knowledge is the most successful in the process of heuristic dialogue interaction, because consideration of various definitions and interpretations is necessary for the conscious and profound mastering of knowledge, as well as collision of the appropriate positions of the participants in the dialogue and finding a certain consensus on the nature and content of the knowledge gained [21]. According to Kahnemann, Mayer and Alexander, formation of the required level of basic theoretical knowledge occurs in case of students' awareness of qualitative or quantitative personal growth, progressive enhancing of their own knowledge, which can either accelerate, or slow down this reorganization $[10,16]$.

The complexity of the process of forming the concepts correlates with the parallel development of abstract and critical thinking. Indeed, both processes require also the facts, assessments, causal relationships, inferences and conclusions, the work with which and over which is conducted in the classroom. Researchers (Tempelaar, Rienties and Nguyen,) also believe that concepts are needed to explain and systematize the 
facts, comprehend other concepts and form basic theoretical knowledge. It is advisable to pay attention to the gradual mastery of key concepts as a result of the enrichment and specification of their content [23]. This approach has its own specific features. It refers to the fact that the acquisition of theoretical knowledge is always a comparison of the achieved result of the students' professional and creative activity with the desired one, that is projected or predicted by them, in accordance with the principle of predictability in heuristic learning.

Petty states that the prognostic function of heuristic learning technologies refers to the prediction of a possible outcome or a possible direction of the educational activity and even visual representation of its image. An indicator of the formation of basic theoretical knowledge is a zero difference between the projected and real outcomes of educational activities. The type of a definite learning activity performed by students is not significant, only the difference between the desired goal and the real one is important. In the process of comparing desired and achieved outcomes, the transformation of the personality of the learner occurs. The construction of the own model of the theoretical concept makes a student correlate the subject of the educational activity and its result with its own content, meaningful for a student personally [19].

The subject of the process is the transformation of the object (material or ideal), and the outcome (or an educational product) of the students' learning activity, that is the assimilation and application of the new system of theoretical knowledge on humanities in their future professional activity. For instance, knowledge of theoretical concepts of a foreign language grammar enables students to find out independently meanings of derivative words, recognize lexical units on formal grounds, match structural and semantic equivalences of a foreign language and a mother tongue. Godwin-Jones noted, that students, after mastering the basic theoretical concepts, can easily and quickly gain foreign languages competences necessary for their future profession, such as to use the dictionary correctly, translate professional and scientific sources from a foreign language into their mother tongue and vice versa [8].

According to Klein, the key component of the heuristic learning technologies is a creative educational product that includes:

1) source, reason for the origin of the object;

2) the nature and functional purpose;

3 ) the internal structure and the system of external interactions [13].

Consideration by students of the listed components forms the basis for constructing their knowledge of a particular object. Creative educational product has two facets of manifestation for the subject of knowledge real and ideal. The real facet is reflected directly in the objects under study - facts, documents, objects, production processes, execution of actions; the ideal one is presented in concepts, categories, laws, theories, scientific principles. Students take a decision about the prospect of their own choice of subject, options and ways of working for a specific outcome, which will then become a means of their further learning activities. It can be a professional problem article on the subject, which is studied, a review of a scientific article, a small research paper, a diagram or a table summarizing the theoretical material, a project of a lesson, a device, experimental equipment, etc. The educational product created by students (knowledge, experience, a method of application, etc.) is presented and discussed in the group and with the teacher. It should be correlated with the analogues that already exist (different scientific methods of solving the same problem situations, versions, hypotheses), as a result of which students' product is being improved, completed, and modified. The defense of the created product (justification of its importance, argumentation of its content and qualitative characteristics) is also a compulsory and effective approach to the acquisition of theoretical knowledge in heuristic learning. Moreover, only under the conditions of independent creation of personally significant educational products, students are interested in mastering basic theoretical and practical aspects of the topic, moreover, to find out personal motives for learning activities [8].

As Willingham wrote, heuristic evaluation would go beyond paper and pencil examinations to involve the consensual validations of student projects by the participants, as well as such tools as methods of heuristic pedagogic diagnostics and diaries which all students would keep of their practical experiences. As appealing and exciting as heuristic approach may be to the innovative-aware teachers and students, some definite weak points have been identified when carried into practice: most undergraduate students, as the result of their post-adolescent personal insecurities and preconceptions of teachers as authority figures, feel tremendously threatened when called upon to play decision-making roles and present materials of their own creation to their 
peers; without the practice of having to work through the intellectual complexities and demands imposed by organized academic process. Students who master humanities as supportive areas for future nonhumanitarian professional purposes do so in superficial and often prejudicial ways [24].

However, the academic process benefits from heuristic productive and creative activities of teachers and students; learning through dialogue; autonomy of teachers in the choice of content of disciplines, methods of assessment, development of critical thinking and skills to solve problems, although it is obvious that many students and teachers are not yet accustomed to the styles of democratic living embodied in heuristic education.

\section{Conclusion}

Modern pedagogical studies in Ukraine and abroad prove that the theory and technology of heuristic activity have a powerful potential for creative learning of theoretical knowledge by students. Heuristic education in the academic process involves the refusal from the reproductive traditional teaching and learning methods and is based on active search and profound comprehension of educational information. Indeed, heuristic academic approach provides the development of critical and creative thinking and professional competences of future specialists in agriculture, their ability to form the necessary knowledge independently. Therefore, heuristic learning technologies are considered to be efficient for humanitarian theoretical knowledge formation of students of agrarian universities due to the involvement of a complex of important pedagogical factors, in particular:

a) motivation of students by identifying the connection between humanitarian theoretical concepts and future professional activities;

b) creation and competent defense of personally significant educational products;

c) teaching students to apply heuristic learning technologies (methods for defining theoretical concepts, methods and tools of dialogue interaction in solving complex professional problems, etc.).

The in-depth analysis of modern scientific sources and experimental survey enabled distinguishing the following stages of humanitarian theoretical concept formation: motivational, searching-creative and reflexing stages. It is proved that the implementation of heuristic learning technologies into the academic process of a higher agricultural school gives students the opportunity to use their intellectual reserve, promotes the development of their abilities to analyze, argue and generate creative ideas and original problem solutions.

\section{Бібліографрічні посилання}

[1] Лазарєв М. О. Основи педагогічної творчості: Суми : Мрія, 2016. 212 с.

[2] Лазарєв М. О. Евристичне навчання - інноваційний феномен креативної освіти / Педагогічна Сумщина. 2008, Вип. № 4, C. 19-20.

[3] Bago, B., \& De Neys, W. Fast logic? Examining the time course assumption of dual process theory/ Cognition, 2017. Iss. 158, P. 90-109.

[4] Beaty, R. E., Silvia, P. J., Nusbaum, E. C., Jauk, E., \& Benedek, M. The roles of associative and executive processes in creative cognition /Memory \& Cognition, 2014, (MAY). P. 1186-1197. doi:10.3758/s13421-014-0428-8

[5] Benedek, M., Jauk, E., Sommer, M., Arendasy, M., \& Neubauer, A. C. Intelligence, creativity, and cognitive control: The common and differential involvement of executive functions in intelligence and creativity/ Intelligence, 2014. Iss. 46, P. 7383. doi:10.1016/j.intell.2014.05.007.

[6] Ben-Horin, H., Pion, C. \& Kali, Y. Designing technology to foster socioscientific reasoning by promoting internal values of learning/ Paper presented at the 12th Chais Conference for the Study of Innovation and Learning Technologies: Learning in the Technological Era, The Open University of Israel, 2016. www.openu.ac.il/innovation/chais2017/f1_2.pdf

[7] Gigerenzer, G., \& Gaissmaier, W. Heuristic decision making / Annual Review of Psychology, 2011. 62, P. 451-482.

[8] Godwin-Jones, R. Augmented reality and language learning: from annotated vocabulary to place-based mobile games/ Language Learning \& Technology, 2016. Iss. 20(3), P. 9-19. http://lt.msu.edu/issues/october2016/emerging.pdf.

[9] Greener, S. Why do research into interactive learning environments? / Interactive learning Environments, Vol. $25,2017$. Issue 4, P. 429-430.

[10] Kahneman, D. Thinking fast and slow. London: Penguin Books. 2012, 240 p.

[11] Katsikopoulos, K. V. Psychological heuristics for making inferences: Definition, performance, and the emerging theory and practice / Decision Analysis, 2011. Iss. 8, P. 10-29.

[12] Kenett, Y. N., Anaki, D., \& Faust, M. Investigating the structure of semantic networks in low and high creative persons / Frontiers in Human Neuroscience, 8(June), 2014. 407 p. doi:10.3389/fnhum.2014.00407. 
[13] Klein, G. A naturalistic decision making perspective on studying intuitive decision making / Journal of Applied Research in Memory and Cognition, 2015. 4, P. 164-168.

[14] Klopfer, E., Osterweil S. \& Salen, K. Moving learning games forward: Obstacles, opportunities and openness. The Education Arcade, 2009. 320 p.

[15] Kurzban, R., Duckworth, A., Kable, J. W., \& Myers, J. An opportunity cost model of subjective effort and task performance / Behavior and Brain Sciences, 2013. 36, P. 661-679.

[16] Mayer, R. E., \& Alexander, P. A. Handbook of research on learning and instruction. Routledge, London, 2011. 257 p.

[17] Melchert, N. The Great Conversation: A Historical Introduction to Philosophy. New York: McGraw Hill, 2002. 459 p. ISBN 019-517510-7.

[18] Ormrod, J. E. Our minds, our memories: Enhancing thinking and learning at all ages. London: Pearson, 2011. 403 p.

[19] Petty, G. Evidence-based teaching: A practical approach. Cheltenham: Nelson Thornes, 2009. 380 p.

[20] Rasmussen, J. Skill, rules and knowledge: Signals, signs and symbols, and other distinctions in human performance models / IEEE Transactions on Systems, Man and Cybernetics, 1983. SMC-13, P. 257-266.

[21] Sale, D. The challenge of reframing engineering education. New York: Springer, 2014. 386 p.

[22] The Free Dictionary, 2014. URL: www.thefreedictionary.co (дата звернення 28.02.2019).

[23] Tempelaar, D. T., Rienties, B. \& Nguyen, Q. Towards actionable learning analytics using dispositions / IEEE Transactions on Learning Technologies, 2017. 1 (Jan-March 2017), P. 6-16. http://ieeexplore.ieee.org/document7839177/.

[24] Willingham, D. T. Why don't students like school: A cognitive scientist answers questions about how the mind works and what it means for the classroom. San Francisco: Jossey-Bass, 2009. $450 \mathrm{p}$.

\section{References}

[1] Lazarev M. O. (2016). Pedagogic creativity. Sumy, Mriya. 212 p.

[2] Lazarev M. O. (2008). Heuristic learning as an innovative phenomenon of creative education. Pedagogy in Sumy region, Iss. 4. $19-20$

[3] Bago, B., \& De Neys, W. (2017). Fast logic? Examining the time course assumption of dual process theory. Cognition, 158, 90-109.

[4] Beaty, R. E., Silvia, P. J., Nusbaum, E. C., Jauk, E., \& Benedek, M. (2014). The roles of associative and executive processes in creative cognition. Memory \& Cognition, (MAY), 1186-1197. doi:10.3758/s13421-014-0428-8.

[5] Benedek, M., Jauk, E., Sommer, M., Arendasy, M., \& Neubauer, A. C. (2014). Intelligence, creativity, and cognitive control: The common and differential involvement of executive functions in intelligence and creativity. Intelligence, 46, 73-83. doi:10.1016/j.intell.2014.05.007

[6] Ben-Horin, H., Pion, C. \& Kali, Y. (2016). Designing technology to foster socioscientific reasoning by promoting internal values of learning. Paper presented at the 12th Chais Conference for the Study of Innovation and Learning Technologies: Learning in the Technological Era, The Open University of Israel. www.openu.ac.il/innovation/chais2017/f1_2.pdf

[7] Gigerenzer, G., \& Gaissmaier, W. (2011). Heuristic decision making. Annual Review of Psychology, 62, 451-482.

[8] Godwin-Jones, R. (2016). Augmented reality and language learning: from annotated vocabulary to place-based mobile games. Language Learning \& Technology, 20(3), 9-19. http://llt.msu.edu/issues/october2016/emerging.pdf.

[9] Greener, S. (2017). Why do research into interactive learning environments? / Interactive learning Environments, Vol. 25, issue 4, p. 429-430.

[10] Kahneman, D. (2012). Thinking fast and slow. London: Penguin Books.

[11] Katsikopoulos, K. V. (2011). Psychological heuristics for making inferences: Definition, performance, and the emerging theory and practice. Decision Analysis, 8, 10-29.

[12] Kenett, Y. N., Anaki, D., \& Faust, M. (2014). Investigating the structure of semantic networks in low and high creative persons. Frontiers in Human Neuroscience, 8(June), 407. doi:10.3389/fnhum.2014.00407

[13] Klein, G. (2015). A naturalistic decision making perspective on studying intuitive decision making. Journal of Applied Research in Memory and Cognition, 4, 164-168.

[14] Klopfer, E., Osterweil S. \& Salen, K. (2009). Moving learning games forward: Obstacles, opportunities and openness. The Education Arcade.

[15] Kurzban, R., Duckworth, A., Kable, J. W., \& Myers, J. (2013). An opportunity cost model of subjective effort and task performance. Behavior and Brain Sciences, 36, 661-679.

[16] Mayer, R. E., \& Alexander, P. A. (2011). Handbook of research on learning and instruction. Routledge, London.

[17] Melchert, N. (2002). The Great Conversation: A Historical Introduction to Philosophy. New York: McGraw Hill. ISBN 0-19517510-7.

[18] Ormrod, J. E. (2011). Our minds, our memories: Enhancing thinking and learning at all ages. London: Pearson.

[19] Petty, G. (2009). Evidence-based teaching: A practical approach. Cheltenham: Nelson Thornes.

[20] Rasmussen, J. (1983). Skill, rules and knowledge: Signals, signs and symbols, and other distinctions in human performance models. IEEE Transactions on Systems, Man and Cybernetics, SMC-13, 257-266.

[21] Sale, D. (2014). The challenge of reframing engineering education. New York: Springer.

[22] The Free Dictionary. (2014). URL: Accessed at www.thefreedictionary.co (accessed 28.02.2019).

[23] Tempelaar, D. T., Rienties, B. \& Nguyen, Q. (2017). Towards actionable learning analytics using dispositions. IEEE Transactions on Learning Technologies, 1 (Jan-March 2017), 6-16. http://ieeexplore.ieee.org/document/7839177/. 
[24] Willingham, D. T. (2009). Why don't students like school: A cognitive scientist answers questions about how the mind works and what it means for the classroom. San Francisco: Jossey-Bass.

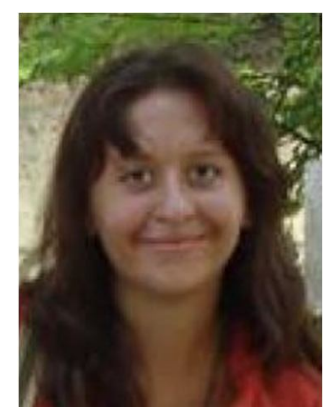

\section{Білоцерковець Марина Анатоліївна.}

Кандидат педагогічних наук, доцент кафедри іноземних мов,

Сумський національний аграрний університет,

вул. Г. Кондратьєва 160, Суми, Україна, 40000.

Тел. 0660076904. E-mail: mbelotserkovets@yahoo.com

\section{Bilotserkovets Maryna Anatoliivna.}

$\mathrm{PhD}$ (in Pedagogy), Associate Professor of the Foreign Languages Department,

Sumy National Agrarian University,

G. Kondratiyev Street 160, Sumy, Ukraine, 40000.

Tel. 0660076904.E-mail: mbelotserkovets@yahoo.com

ORCID: 0000-0003-4692-3444

Researcher ID: V-4829-2018

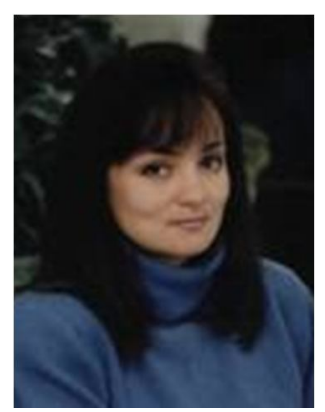

\section{Бересток Ольга Володимирівна.}

Старший викладач кафедри іноземних мов,

Сумський національний аграрний університет,

вул. Г. Кондратьєва 160, Суми, Україна, 40000.

Тел. 0955555018. E-mail: berestok@email.ua

\section{Berestok Olha Volodymyrivna.}

Senior Lecturer of the Foreign Languages Department,

Sumy National Agrarian University,

G. Kondratiyev Street 160, Sumy, Ukraine, 40000.

Tel. 0955555018. E-mail: berestok@email.ua

ORCID: 0000-0001-7912-9592

Researcher ID: V-4039-2018

\section{Citation (APA):}

Bilotserkovets, M., Berestok, O. (2019). Implementation of heuristic learning technologies for theoretic concepts formation by students mastering agricultural professions. Engineering and Educational Technologies, 7 (1), 36-45. doi:

https://doi.org/10.30929/2307-9770.2019.07.01.04

\section{Цитування (ДСТУ 8302:2015):}

Білоцерковець М. А., Бересток О. В. Впровадження евристичних технологій навчання для формування теоретичних понять студентами-аграріями / Інженерні та освітні технології. 2019. Т. 7. № 1. С. 36-45. doi: https://doi.org/10.30929/23079770.2019 .07 .01 .04

Обсяг статmі: $\quad$ сторінок - 10 ; умовних друк. аркушів - 1,149 